\title{
Environmental drivers of fish spatial distribution and activity in a reservoir with water level fluctuations
}

\section{Rôle des facteurs environnementaux sur la distribution spatiale et l'activité des poissons dans une retenue soumise à marnage}

\author{
R. Roy ${ }^{1}$, L. Tissot ${ }^{1}$, C. Argillier ${ }^{2}$ \\ ${ }^{1}$ EDF Recherche et Développement, Laboratoire National d'Hydraulique et Environnement, HYNES \\ (Irstea-EDF R\&D), 6 quai Watier, 78401 Chatou cedex, France \\ r.roy@profish-technology.fr \\ 2 Irstea, UR HYAX, HYNES (Irstea-EDF R\&D), 3275 Route de Cézanne CS 40061, \\ 13182 Aix-en-Provence cedex 5, France
}

\begin{abstract}
The aquatic ecosystem structuration in human influenced environment, is closely dependent of the associated uses, which are generally fluctuant. We conducted an extended field monitoring on a reservoir under water level fluctuations (WLF), in order to study the responses of fish fauna to changes in environmental conditions. The study design was based on a monitoring of fish behaviour by telemetry in a reservoir with a particular attention to the littoral zone because of its front line position during WLF. The results of this study, which was conducted on the Bariousses reservoir, located on the Vézère river (Corrèze, France), are summarized in this article. The study revealed that WLF induced a temporal variability in the littoral zone surface. In addition, we observed a gradual decline in structural complexity of littoral habitats with a tendency towards homogenisation (dominance of fine substrates and absence of vegetation) in relation with the drop in water level. Behavioural individual responses of pikeperch, perch and pike were highly variable in relation to environmental fluctuations. Temperature and photoperiod were the two main parameters controlling fish activity and spatial distribution. Water level affected part of fish assemblage: some individuals were more mobile and left the littoral zone when inshore habitats were less complex (low water level).
\end{abstract}

Keywords - reservoir; littoral habitat; fish; water level fluctuations; acoustic telemetry.

Résumé - Le fonctionnement des milieux, aquatiques soumis à des pressions anthropiques, est étroitement dépendant des usages générant des fluctuations de l'environnement des communautés biologiques. Nous avons mené une étude sur une retenue soumise à des fluctuations du niveau de l'eau (WLF), afin d'étudier les réponses de l'ichtyofaune aux changements des conditions environnementales. Un suivi du comportement des poissons par télémétrie acoustique a été mené avec une attention particulière portée à la zone littorale car elle est fortement soumise aux WLF. Les résultats de cette étude sur la retenue des Bariousses, localisé sur la Vézère (Corrèze, France) sont synthétisés dans cet article. Nous avons mis en évidence que les fluctuations du niveau de l'eau induisent une variabilité 
temporelle de la surface occupée par la zone littorale. De plus, une diminution progressive de la complexité structurelle des habitats littoraux avec une tendance à l'homogénéisation (dominance des substrats fins et de l'absence de végétation) est observée suite à un abaissement du niveau de l'eau. Les réponses comportementales du sandre, de la perche et du brochet étaient fortement variables en fonction des conditions environnementales. La température et la photopériode représentent deux paramètres structurant majeurs de l'activité et du choix des habitats. Le niveau d'eau affecte une partie du peuplement ; certains individus sont plus mobiles et ont tendance à fréquenter de façon moindre la zone littorale lorsque les habitats de bordures sont faiblement complexes (faible niveau d'eau).

Mots-clés - retenue ; habitat littoral ; poissons ; variations de niveau d'eau ; télémétrie acoustique.

\section{Introduction}

Reservoirs are man-made lakes constructed for different purposes: electricity production, water supply, irrigation or provision of water for domestic and industrial uses (Day \& Garratt, 2006). For example, hydroelectricity supplies $16.2 \%$ of the electricity requirements worldwide (Observ'ER, 2013). At the end of the 20th century, there were 45000 large dams built for multiple purposes in more than 140 countries (World-Commission-onDams, 2000). From a hydrological point of view, functioning of reservoirs differs from the one of natural lakes because of variations in water level related to flow rate control. Water level fluctuations (WLF) may be strong and irregular in reservoir, whereas they are generally weak and stable in lake (Wetzel, 1990). This parameter is a major driver controlling lake ecosystem functioning (Wilcox \& Meeker, 1992; Poff et al., 1997; Leira \& Cantonati, 2008). Total amplitude and temporal variability constitute the two main characteristics (Poirel et al., 2001).

The lowering of water level or more generally WLF has a direct impact on physical characteristics of reservoirs: they may alter the basin morphometry (Leira \& Cantonati, 2008), intensify erosion, transform sedimentation zones (Gafny \& Gasith, 1993; Leira \& Cantonati, 2008) or alter the thermal regime (Leira \& Cantonati, 2008). The overall functioning of lake ecosystems is closely dependent on the littoral zone, which is under strong pressure induced by WLF (Wetzel, 1990; Schindler \& Scheuerell, 2002; Strayer \& Findlay, 2010). Several studies observed impacts of a water level drop with an alteration of littoral habitats availability and a decline in littoral habitats complexity (Gasith \& Gafny, 1990; Beauchamp et al., 1994; Zohary \& Ostrovsky, 2011). Nevertheless, to our knowledge, none quantified precisely composition changes at a whole reservoir scale. Due to the link between biological functions and environmental conditions, these changes can also induce modifications of the biocenosis.

Among aquatic organism, fishes concentrate economic, social and patrimonial interests. Indeed, in reservoirs, angling may represent high economic value (Irz et al., 2002) and they host some native species of interest like pike (Esox lucius (L.)) and trout (Salmo trutta (L.)). Because of their top position 
within the food web (Ramade, 2009), they may represent the global functioning of the ecosystem. In addition, they have a long-life cycle (several years) requiring various types of habitats or functional units for each stage of their development and vital requirements (reproduction, feeding and protection) (Schlosser, 1995), which can make them more vulnerable.

Indirect effects of WLF on reservoir fish populations related to changes in habitat conditions, were well identified (Sutela \& Vehanen, 2008). WLF may alter spawning habitats availability and, as a consequence, reproduction success (Gafny et al., 1992; Clark et al., 2008; Kahl et al., 2008), with different sensitivity degrees according to species requirements in terms of spawning substrates. Analysis of time series allows to relate water level and amplitude of WLF with spawning success or failure and thus with population dynamic (Ostrovsky \& Walline, 2000; Kahl et al., 2008; Webb, 2008; Ostrovsky et al., 2013). In addition, WLF alter number of fish refuges (Gasith et al., 2000; Fischer \& Ohl, 2005). Finally, alteration of tropic resources (in particular, invertebrates and plankton) for fish species is also a consequence of WLF. For example, significant changes in composition of macro-invertebrates communities were observed in relation with WLF (Smith et al., 1987; Valdovinos et al., 2007; Aroviita \& Hamalainen, 2008; Baumgartner et al., 2008; Brauns et al., 2008; White et al., 2008). Several studies contributed to improve knowledge of direct or indirect effects of WLF on fish fauna. They pointed towards the potential alteration of all the vital functions of fish species (survival, growth and reproduction), via environmental alteration by hydraulic control of reservoirs. However, these studies generally refer to the alteration of one particular process, such as the impact on recruitment or alteration of diet for a particular species. In addition, in most of them, quantification of process intensity and evaluation of its impact on species dynamic are not assessed (Rose, 2000). Temporal dynamic of the relationships between fish fauna and its environment under hydrological pressure were rarely described.

In this context, our objective was to characterize how the fish fauna was structured by environmental changes (hydrology, water temperature and photoperiod) in a medium-sized reservoir impacted by WLF. The study design was based on a multi-scale approach, both biological (community and individual) and temporal (annual and diurnal cycles), with a particular attention devoted to the littoral zone because of its front-line position during WLF (Fig. 1). We focused on improving knowledge on links between fish assemblages and physical drivers thanks to an extended field monitoring on one reservoir.

More precisely, we first quantified the impacts of WLF on the availability and the quality of littoral habitats at the whole reservoir scale. The hypothesis tested was that complexity and diversity of littoral habitats decline with the lowering of water level due to disappearance of the shoreline vegetation and to predominance of fine substrates.

Then, we focused on the individual adult behaviour of three piscivorous species occurring in the reservoir, i.e. pikeperch (Sander lucioperca (L.)), perch (Perca fluviatilis (L.)) and pike. 


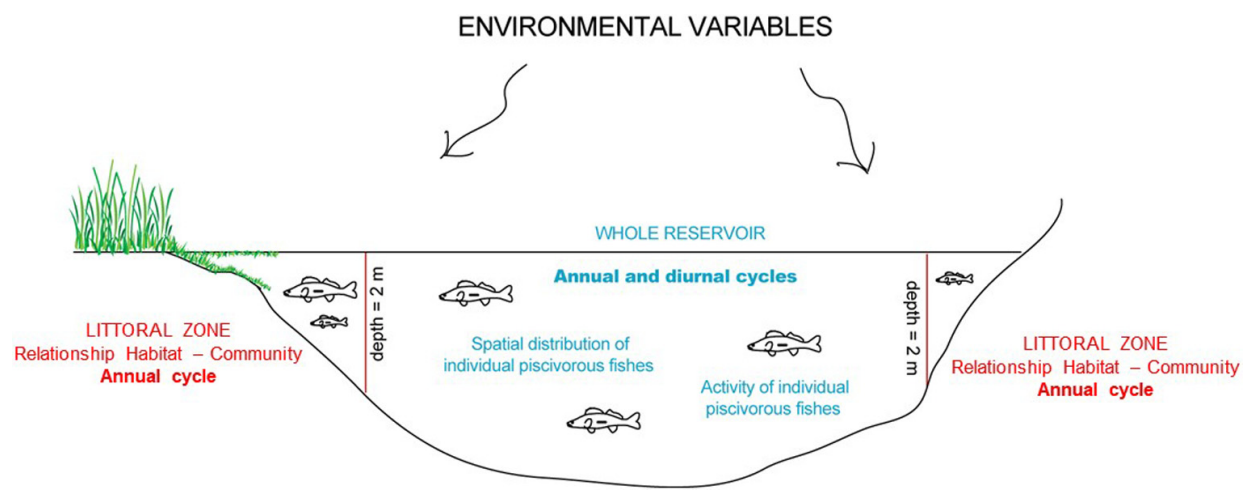

Fig. 1. Diagram of the approach adopted.

Fig. 1. Schéma de la démarche adoptée.

The effects of WLF, temperature and photoperiod on the activity and the spatial distribution patterns were studied. The presence in the littoral zone and the activity of these three species are assumed to be very strongly influenced by temperature and photoperiod (Zamora \& Moreno-Amich, 2002; Horky et al., 2008). Nevertheless, variations in water level are also expected to be a structuring parameter. Assumptions that the littoral zone is less attractive and that mobility is higher when habitats are more homogeneous were tested.

This study was conducted on the Bariousses reservoir, located on the Vézère river (Corrèze, France). This article presented a synthesis of all the methods, results and conclusions obtained during a PhD (Roy et al., 2014).

\section{Study site}

Bariousses reservoir is an impoundment of the Vézère River in west central
France, located at an altitude of $516 \mathrm{~m}$ $\left(45.33^{\circ} \mathrm{N}, 1.49^{\circ} \mathrm{E}\right)$ (Fig. 2). It is operated by Electricité De France (EDF). The upstream drained watershed is $229 \mathrm{~km}^{2}$. The reservoir has an area of $80.9 \mathrm{ha}$, a perimeter of $9.9 \mathrm{~km}$, and mean and maximum depths of $7.1 \mathrm{~m}$ and $18.9 \mathrm{~m}$, respectively. Its volume is $5,707,290 \mathrm{~m}^{3}$, with a mean renewal time of twelve days. It is monomictic with a period of summer stratification. Its last draining was in 1997. WLF observed in this reservoir result of hydropeaking of Monceaux (upstream) and Treignac (downstream) hydroelectric powerplants. WLF total amplitude is $12 \mathrm{~m}$ (under normal operation, maximum and minimum water level are $513 \mathrm{~m}$ NGF and $501 \mathrm{~m}$ NGF respectively), but WLF total amplitude did not exceed $6.2 \mathrm{~m}$ between $1 \mathrm{st}$ January 2011 and 20th May 2013 (507.3-513.5 m NGF) for an average daily level of $511.4 \mathrm{~m}$ NGF. The Bariousses reservoir displays a large heterogeneity of water levels. WLF do not follow either a seasonal or a weekly pattern. 


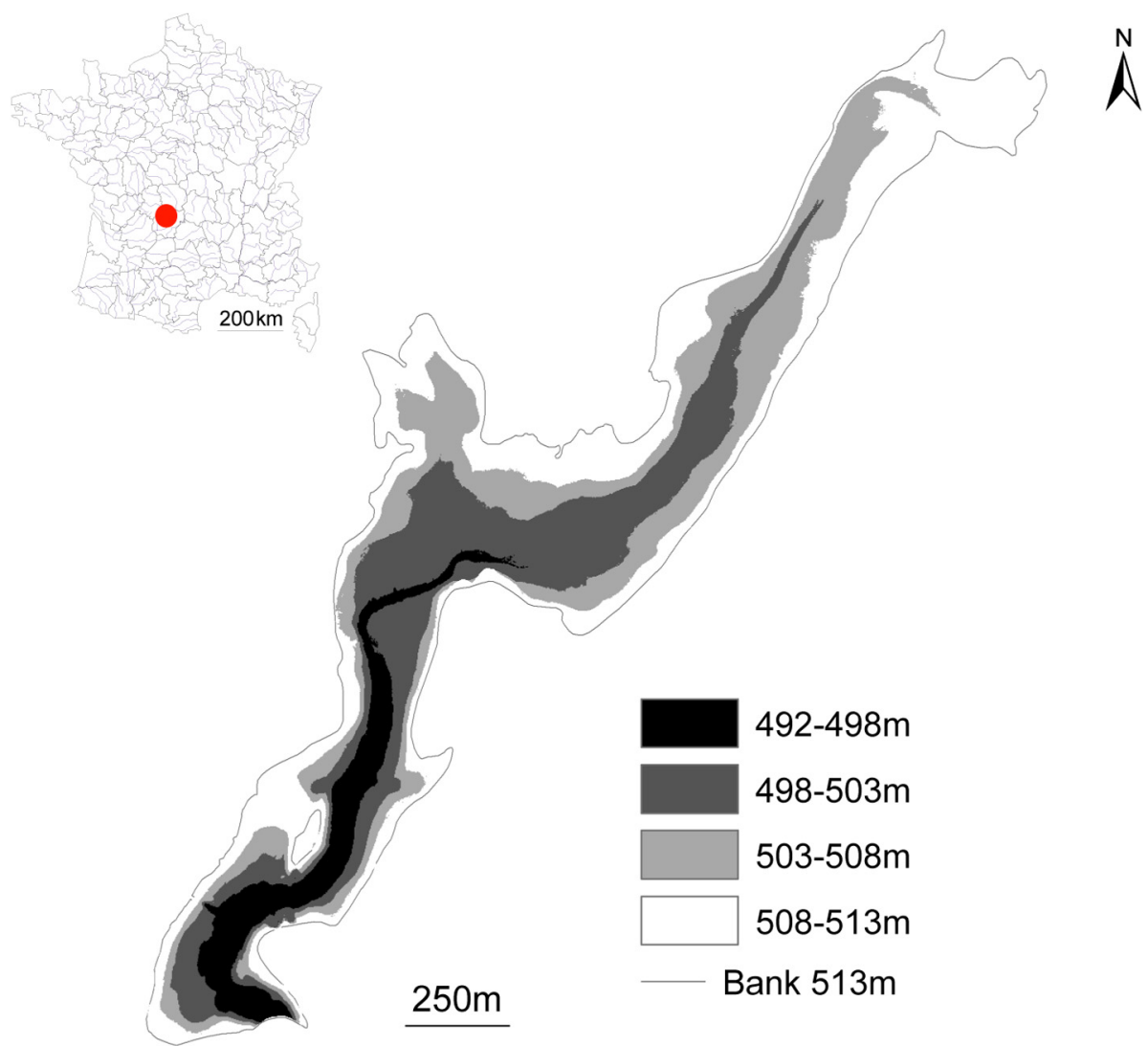

Fig. 2. Location of the Vézère River in France and map of the Bariousses reservoir with altitudinal contour lines.

Fig. 2. Localisation de la rivière Vézère en France et bathymétrie de la retenue des Bariousses.

In addition, of WLF induced by hydroelectric production, the Bariousses reservoir is located in a rural and natural environment, in a catchment dominated by forestland cover with low anthropogenic activities (Rebière et al., 2012). At the average water level, this reservoir presents diversified littoral habitats and low shore degradation (except dam). Moreover, fish community is quite comparable to that encountered in many French reservoirs and two of the three piscivorous focused species (i.e. perch and pikeperch) are not controlled by the fishery management authorities. The Bariousses reservoir has mean physical and hydrological characteristics that well represent a part of EDF other reservoirs, particularly in the MassifCentral.

In 2010, the fish community of the Bariousses' reservoirs was sampled with multimesh gillnets following the Nordic standardised protocol (C.E.N., 2005). Eleven species were identified: Pike, Pikeperch, Perch, Bream (Abramis brama (L.)), Carp (Cyprinus carpio 
(L.)), Chub (Leuciscus cephalus (L.)), Roach (Rutilus rutilus (L.)), Ruffe (Gymnocephalus cernua (L.)), Pumpkinseed (Lepomis gibbosus (L.)), Rudd (Scardinius erithrophthalamus (L.)), and Tench (Tinca tinca L.). The community was dominated by roach that represent $52 \%$ of the number of fish caught and $24 \%$ of the biomass. Then ruffe and perch were most frequent (27 and $10 \%$ of the fish caught respectively) whereas carp and tench were the most abundant in biomass (17\% and $16 \%$ respectively).

During this 3 years study, additional electrofishing samplings in the littoral habitat highlight the presence of 4 additional species: Wels Catfish (Silurus glanis (L.)), European brook lamprey (Lampetra planeri (Bloch. 1784)), Dace (Leuciscus burdigalensis (L.)) and Brown trout.

\section{Materials and methods}

The extended field monitoring included a field mapping of area affected by WLF and an individual monitoring of fish equipped with acoustic tags.

\subsection{Habitats}

A bathymetric map was determined by a multibeam sounder in March 2012 (source Engineering unit DTG of EDF). The littoral zone was defined by areas with a depth less than $2 \mathrm{~m}$. Littoral habitat (substrate and vegetation) described by the CHARLI protocol (Alleaume et al., 2014) was mapped between 508 and $513.5 \mathrm{~m} \mathrm{NGF}$ with a differential GPS. The variations of the littoral zone area and the proportions of the littoral habitat types were observed between 4 water levels: 513.5, 512.5, 511.5 and $510.5 \mathrm{~m} \mathrm{NGF.}$

\subsection{Spatial distribution and activity of perch, pike and pikeperch}

An acoustic VEMCO telemetry system was deployed on the whole reservoir during one year. Thirty hydrophones were set close to the isobaths $507 \mathrm{~m}$ NGF (i.e. maximal depth of $6.5 \mathrm{~m}$ ) and ten additional hydrophones were set in depth higher than $6 \mathrm{~m}$ in order to monitor fish in the whole reservoir.

Thirty-six adults of pikeperch, twenty-seven adults of pike and twentyseven adults of perch were caught by anglers and multimesh gillnets set during very short period in order to limit the stress. Fifty-four fish were equipped with acoustic tag in order to analyse their spatial distribution and thirty-three to characterize their activity (Roy, 2014).

The "VEMCO Positioning System (VPS)" was used to calculate 2D positions of tagged fish (VEMCO Division, 2008, 2013; Smith, 2013). Under test conditions, mean positioning error of our system was $3.3 \mathrm{~m}$ (standard deviation of $3.3 \mathrm{~m}$ ) and probability of location was $40 \%$ after filtering out aberrant positions $(79 \%$ of positions maintained) (Roy, 2014).

Each fish position was associated with 7 environmental variables to characterize photoperiod, temperature and water level (Tab. I).

Spatial distribution was defined first by the presence/absence of the fish in the littoral zone then by the water column height at the fish location 
Table I. Environmental variables describing each fish position.

Tableau 1. Variables environnementales associées à chacune des positions de poissons.

\begin{tabular}{|c|c|c|}
\hline Identifier & Type & Description \\
\hline PHOTOPERIOD (PP) & Category & $\begin{array}{l}\text { Four phases of the day: 'Dawn' and 'Dusk' } \\
\text { covering for two hours the sunrise and sunset } \\
\text { and 'Day' and 'Night', corresponding to hours } \\
\text { recorded between Dawn and Dusk. }\end{array}$ \\
\hline TEMP_S (MT) & Numerical & $\begin{array}{l}\text { Mean daily water temperature, } 50 \mathrm{~cm} \text { below the } \\
\text { surface }\left({ }^{\circ} \mathrm{C}\right) \text { in downstream part of the reservoir }\end{array}$ \\
\hline WATER_LEVEL_DAY (WL) & Numerical & $\begin{array}{l}\text { Mean daily water level of the reservoir (m NGF) } \\
\text { calculated on hourly data }\end{array}$ \\
\hline ABS_AMP_DAY (WLDif_D) & Numerical & $\begin{array}{l}\text { Absolute value of the difference between the } \\
\text { mean water level of day } \mathrm{J} \text { and day } \mathrm{J}-1(\mathrm{~m})\end{array}$ \\
\hline DIRECTION_DAY (WLFD_D) & Category & $\begin{array}{l}\text { Direction of WLF since the previous day. This is a } \\
\text { two-mode variable: fall and rise }\end{array}$ \\
\hline $\begin{array}{l}\text { ACCUM_ABS_AMP_WEEK } \\
\text { (WLDif_W) }\end{array}$ & Numerical & Sum of the ABS_AMP_DAY over the last 7 days $(\mathrm{m})$ \\
\hline DIRECTION_WEEK (WLFD_W) & Category & $\begin{array}{l}\text { Direction of WLF since the last } 7 \text { days. This is a } \\
\text { two-mode variable: fall and rise }\end{array}$ \\
\hline
\end{tabular}

Table II. Mean values of water temperature $\left({ }^{\circ} \mathrm{C}\right)$ and water level (m NGF) for each season.

Tableau 2. Valeurs moyennes de la température de l'eau $\left({ }^{\circ} \mathrm{C}\right)$ et du niveau de l'eau (m NGF) pour chacune des saisons.

\begin{tabular}{llll}
\hline & Summer & Autumn & Winter \\
\hline Duration & 29 June 2012 to & 05 October 2012 to & 21 December 2012 to \\
TEMP_S (MT) & 07 August 2012 & 20 December 2012 & 20 May 2013 \\
WATER_LEVEL_DAY (WL) & 511.8 & 10.4 & 4.7 \\
\hline
\end{tabular}

(HW) and its distance to the closest shore (Dr). A total of 1168576 positions corresponding to movement of 25 pikeperch (143-695 $\mathrm{mm}), 19$ perch $(320-486 \mathrm{~mm})$ and 10 pike (425$629 \mathrm{~mm}$ ), monitored over 283 days from 11 March 2012 to 20 May 2013 were analysed. These spatial distributions were analysed depending on the seasons. In terms of temperature and hydrological conditions, the different periods selected are highly contrasted (Tab. II).

Fish activity was described by two metrics. The minimal distance covered in one day was calculated when a minimum of 8 positions were observed at dawn, 24 at daylight, 8 at dusk and 24 at night (a minimum of 64 positions per day). On average, a distance value covered by day was calculated with 314 positions. The number of distance covered per day finally available was 1765 for the pikeperch, 1110 for the perch and 308 for the pike. The home range corresponding to the area where a fish stays $95 \%$ of the time (HR95) (Parsons et al., 2003; Katajisto \& Moilanen, 2006) was assessed by the Brownian Bridge Movement Model (BBMM) (Horne et al., 2007) using the "kernelbb" function of the R package "adehabitatHR" (Calenge, 2006, 2013). This metric was calculated at the 
diurnal and seasonal scales. A total of 1512381 positions corresponding to movement of 28 pikeperch (143$695 \mathrm{~mm}), 21$ perch $(240-486 \mathrm{~mm})$ and 14 pike (375-629 $\mathrm{mm}$ ) during 405 days from 11 March 2012 to 20 May 2013 were considered.

\subsection{Data analyses}

The relationships between mean daily values of HW and $\mathrm{Dr}$ measurements for each species and water temperature were tested using a Spearman correlation coefficient (excluding spring period).

The influence of the 7 environmental variables listed in Table I \& II (3 qualitatives: PP, WLFD_D and WLFD_W; 4 numericals: MT, WL, WLDif_D and WLDif_W) on the presence / absence (binary variable, 0 or 1 ) of fish individuals in the littoral zone (excluding spring period) was analysed by a logistical regression $(n=30)$. Hierarchical partitioning was then implemented to determine explanatory power (explained variance) of each environmental variable (Chevan \& Sutherland, 1991). A PCA was then applied on contribution values of each environmental variable to compare individual responses to the explanatory variables.

Multiple regressions by individual $(n=20)$ were used to predict daily activity described by the numerical variable daily distance covered during the spring period in function of the 4 numerical environmental variables (MT, WL, WLDif_D and WLDif_W). Beforehand, daily distance has been transformed by $\log (x+1)$ to make the distributions more symmetrical and each numerical variable has been normalized. A redundancy analysis has been used to do a partitioning of variance for each environmental variable (Legendre \& Legendre, 1998).

All statistical analyses were performed using R software (R.C.T, 2012).

\section{Results}

\subsection{Impact of water level fluctuations on littoral habitats}

\subsubsection{Littoral habitat}

During the study period, WLF induced variations in surface occupied by the littoral zone. The area varied between 9 and 14 ha (between 9.3 and $14.4 \%$ of the total surface of the reservoir). Surface of the littoral zone reached a maximum at $510.9 \mathrm{~m} \mathrm{NGF}$ but this level was observed only $2.1 \%$ of the time.

At maximum recorded water level (513.5 m NGF), lawn, and more characteristic of terrestrial habitats than of lake habitats, dominated the littoral zone (Tab. III and Fig. 3). The littoral zone was also characterized by a high proportion of shoreline bordered by submerged vegetation, which provided riparian shade and habitats complexity (roots and tree branches). Nevertheless, maximum water level was seldom reached (124 days between 1997 and 2013) and was thus poorly representative of the mostly encountered conditions by organisms.

The lowering of water level led to a gradual increase in the littoral habitats with sandy and silt substrates, but coarse substrates remained poorly represented (Tab. III, Figs. 3 and 4). Vegetation, spawning substrate for pike particularly, was present above 
Table III. Percentages of surface occupied by each substrate and bank vegetation categories in the littoral zone observed at 513.5, 512.5, 511.5 and 510.5 m NGF.

Tableau 3. Pourcentages surfaciques occupés par chacune des catégories de substrat et de végétation de rive observés en zone littorale aux cotes $513.5,512.5,511.5$ et $510.5 \mathrm{~m}$ NGF.

\begin{tabular}{llccrr}
\hline & Categories & 513.5 & 512.5 & 511.5 & 510.5 \\
\hline \multirow{6}{*}{ Substrate } & Silt & 3.5 & 20.5 & 31.4 & 42.3 \\
& Sand & 5.2 & 12.2 & 19.1 & 24.7 \\
& Gravel & 7.9 & 16.8 & 16.5 & 10.7 \\
& Pebbles & 0.3 & 1.5 & 1.7 & 0.6 \\
& Stones & 2.1 & 5.6 & 7.1 & 6.4 \\
& Boulders & 0.2 & 0.3 & 0.3 & 0.3 \\
& Large rocks & 2.9 & 6.7 & 10.1 & 11.0 \\
& Slabs & 1.0 & 1.7 & 2.5 & 2.3 \\
& Unknown & 1.8 & 2.6 & 2.7 & 1.2 \\
& Lawn & 75.2 & 32.2 & 8.5 & 0.5 \\
& Submerged vegetation & 72.7 & 41.4 & 17.4 & 4.9 \\
& Riparian shade & 71.4 & 40.9 & 17.3 & 5.3 \\
& Herbaceous & 12.8 & 9.3 & 6.0 & 1.9 \\
& Helophytes & 5.0 & 6.8 & 3.5 & 0.4 \\
& Litter & 0 & 0 & 0.01 & 0.02 \\
& Dead ligneous & 0 & 0 & 0.01 & 0.02 \\
\hline
\end{tabular}

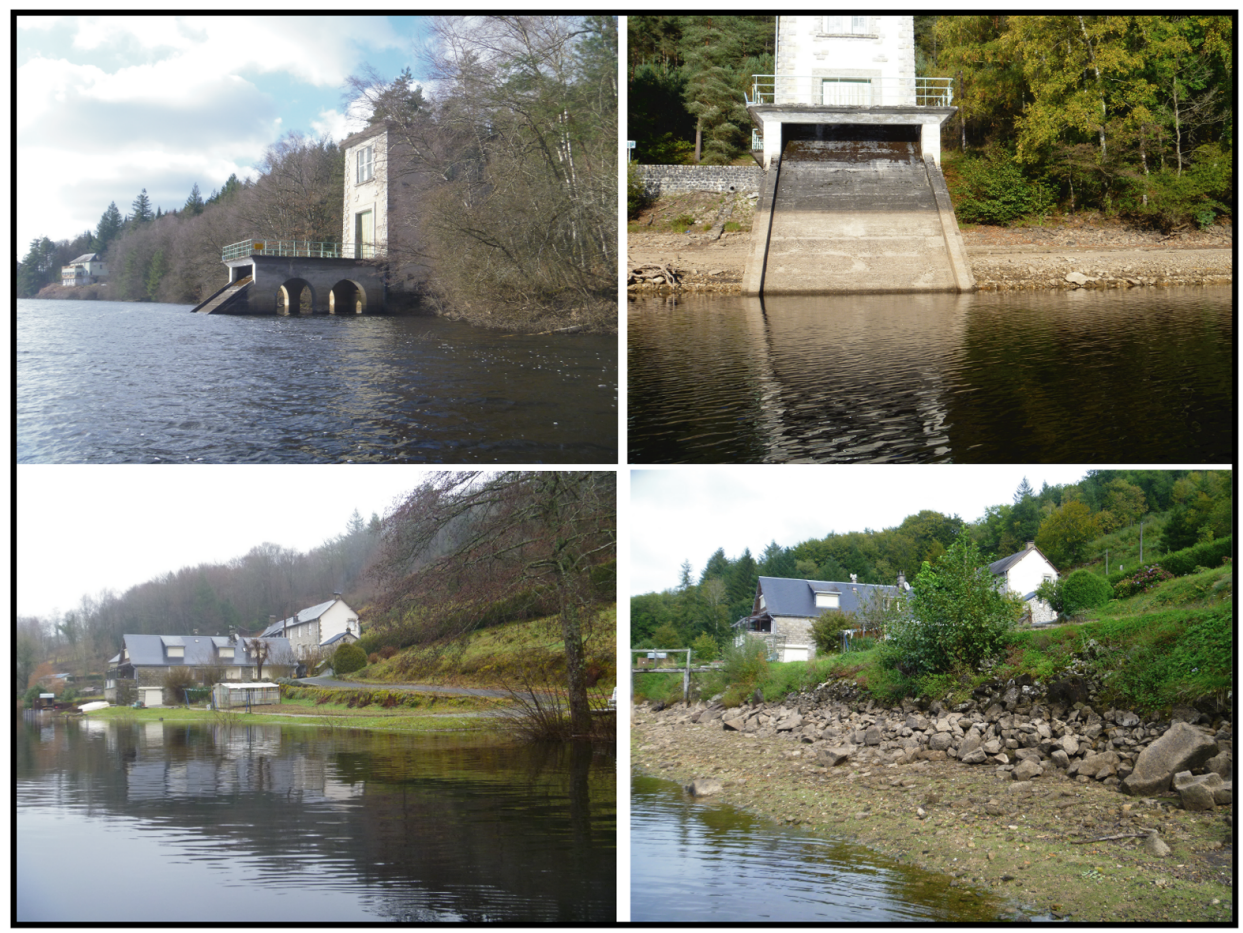

Fig. 3. Changes in the littoral habitat of the Bariousses reservoir with a drop in water level from 513 NGF (left) to $510 \mathrm{~m}$ NGF (right).

Fig. 3. Évolution des habitats de rive de la retenue des Bariousses au cours d'un abaissement du niveau de l'eau entre 513 NGF (à gauche) et 510 m NGF (à droite). 

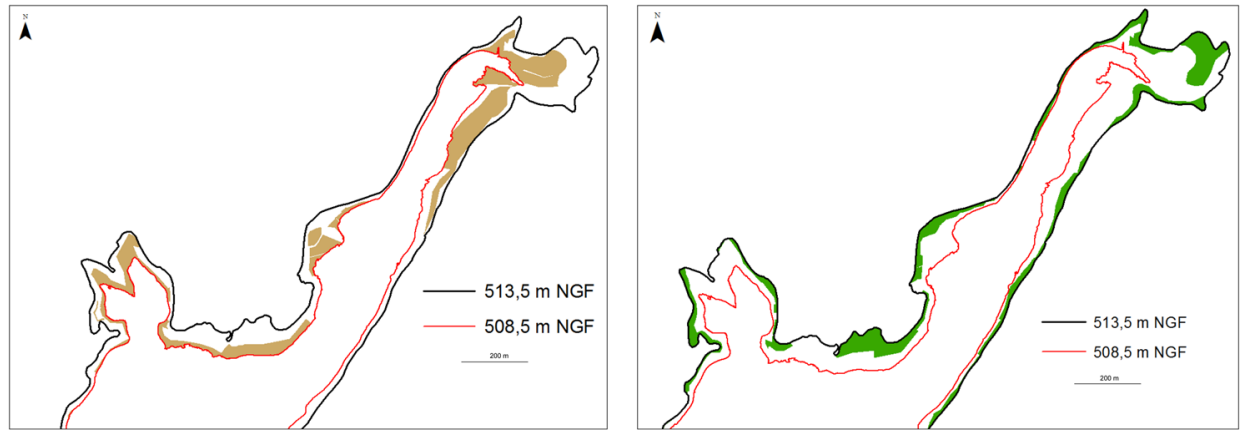

Fig. 4. Map of the area occupied by silt (left) and by submerged vegetation (right), in the upstream part of the reservoir, between 513.5 (black) and $508.5 \mathrm{~m} \mathrm{NGF}$ (red).

Fig. 4. Cartographie de la surface occupée par la vase (à gauche) et par les ligneux émergents (à droite), dans la partie amont de la retenue, entre les cotes 513.5 (en noir) et $508.5 \mathrm{~m} \mathrm{NGF}$ (en rouge).

511.5 m NGF and was gradually disconnected with the fall in water level. Between 1997 and 2013, in March, generally the spawning period for pike on this reservoir, this $511.5 \mathrm{~m}$ NGF level was only exceeded on $22.2 \%$ of days.

\subsubsection{Spatial distribution of individuals}

Within each species, individuals may occupy quite different areas (Fig. 5). For example, in summer, pikeperch T35 and perch T55 spent time in the whole reservoir; pikeperch T01, perch T28 and T48 and pike T46 were rather in the upstream area; pikeperch T02 and pike T16 occupied mainly the downstream area whereas pike T04 was rather confined to the intermediate area. This cartographical analysis of distribution patterns for all monitored individuals showed that the whole reservoir was well occupied.

The spatial distribution pattern of individuals of the three species differed quite distinctly between summer and winter (Tab. IV). In winter, with drop in water temperature, fish moved signifi- cantly in areas further from the shore and deeper (Tab. V). Whatever the species and the season, there was high inter-individual variability of depth of water column and distance from the shore occupied by tracked fish (Tab. IV).

The logistical regression models correctly predicted the frequentation of the littoral zone. Method of hierarchical partitioning showed a clear influence of PP and of MT on the presence of 22 individuals in the littoral zone; their mean contributions were respectively $44 \%$ (12-95\%, according to individuals) and 40\% (11-83\% according to individuals). In addition, the model coefficients showed that the monitored individuals were more likely to be present in the littoral zone than in the pelagic area, at night (7.9 times more on average), at dawn (4.6 times more on average) and at dusk (5.4 times more on average) than during the day. Finally, with an increase in water temperature of $1^{\circ} \mathrm{C}$, individuals were on average 1.7 times more likely to be in the littoral zone than in the pelagic zone of the reservoir. 

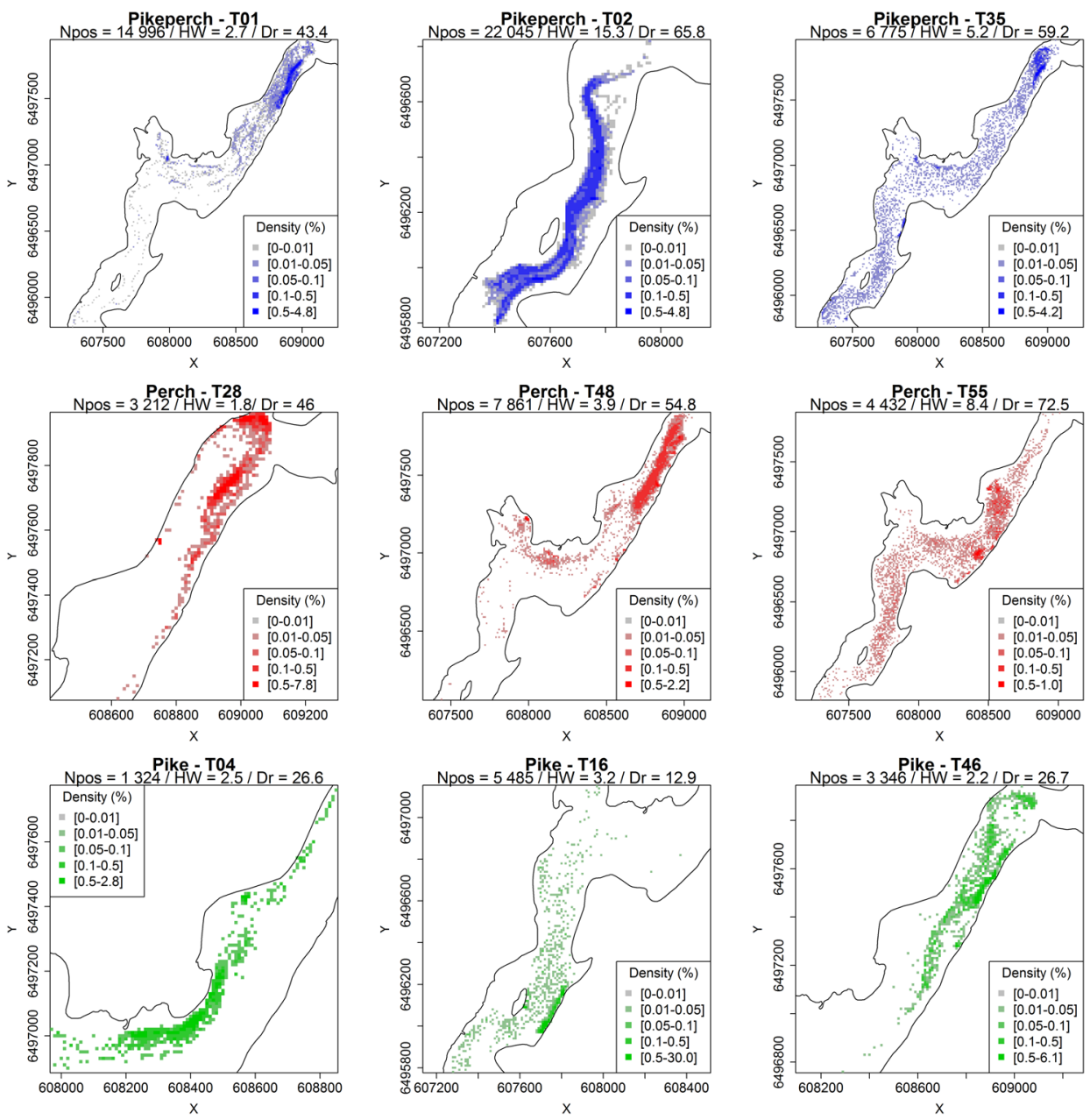

Fig. 5. Map of presence density with a square mesh of $10^{*} 10 \mathrm{~m}$ for 3 pikeperch individuals (T01, T02, T35, in blue), 3 perch individuals (T28, T48, T55 in red) and 3 pike individuals (T04, T16, T46, in green) during summer.

Fig. 5. Carte de densité de présence avec une maille carrée de $10^{\star} 10 \mathrm{~m}$ pour 3 individus de sandre (T01, T02, T35, en bleu), 3 individus de perche (T28, T48, T55, en rouge) et 3 individus de brochet (T04, T16, T46, en vert) en période estivale.

The water level of the reservoir WL also had an influence on the use of the littoral zone, but to a lesser extent. Mean contribution was $31 \%$ for the mean diurnal water level $(n=10,13-$ $60 \%$, according to individuals). The model coefficients showed that individ- uals were on average 5.7 times less likely to be present in the littoral zone than in the pelagic zone of the reservoir with a drop-in water level of $1 \mathrm{~m}$.

The descriptive parameters of the past variations in water level selected in this analyse (WLDif_D, WLFD_D, WLDif_W 
Table IV. Mean values for the two metrics of spatial distribution, total depth of water column (HW in $\mathrm{m}$ ) and distance from the shore ( $\mathrm{Dr}$ in $\mathrm{m}$ ), for each species, and range of variability between individuals in italics, in summer and winter (Npos = sample size and Nind = number of individuals).

Tableau 4. Valeurs moyennes des deux métriques de distribution spatiale, hauteur totale de la colonne d'eau ( $\mathrm{HW}$ en $\mathrm{m}$ ) et distance à la rive ( $\mathrm{Dr}$ en $\mathrm{m}$ ) pour chacune des espèces et gamme de variabilité interindividuelle en itallique, en été et en hiver (Npos = taille de l'échantillon et Nind=nombre d'individus).

\begin{tabular}{|c|c|c|c|c|c|c|}
\hline & \multicolumn{2}{|c|}{ Pikeperch } & \multicolumn{2}{|c|}{ Perch } & \multicolumn{2}{|c|}{ Pike } \\
\hline & Summer & Winter & Summer & Winter & Summer & Winter \\
\hline Npos & 118181 & 149941 & 59955 & 187043 & 15848 & 44130 \\
\hline \multirow[t]{2}{*}{ Nind } & 20 & 11 & 12 & 12 & 6 & 6 \\
\hline & 6.6 & 9.2 & 4.1 & 6.9 & 2.6 & 6.3 \\
\hline HW & $2-15.3$ & $4.2-12.7$ & $1.8-8.4$ & $3.8-12.2$ & $2.2-3.2$ & $4-9.5$ \\
\hline \multirow[t]{2}{*}{$\mathrm{Dr}$} & 51.4 & 87.1 & 44.4 & 53.5 & 22.5 & 52.5 \\
\hline & $6.2-66.6$ & 50.4-120.5 & $14.5-72.5$ & $14.2-97.7$ & $12.9-30.2$ & $24.7-64.9$ \\
\hline
\end{tabular}

Table V. Results for Spearman correlation analysis between mean daily water temperature and the metrics depth of water column (HW in $\mathrm{m}$ ) and distance from the shore ( $\mathrm{Dr}$ in $\mathrm{m}$ ).

Tableau 5. Résultats de l'analyse de corrélation de Spearman entre les valeurs moyennes journalières de la température de l'eau et des deux métriques hauteur de colonne d'eau (HW en mètre) et distance à la rive $(\mathrm{Dr}$ en $\mathrm{m})$.

\begin{tabular}{llll}
\hline & Pikeperch & Perch & Pike \\
\hline $\mathrm{HW}$ & $r=-0.71, P<0.0001$ & $r=-0.80, P<0.0001$ & $r=-0.57, P<0.0001$ \\
$\mathrm{Dr}$ & $r=-0.65, P<0.0001$ & $r=-0.45, P<0.0001$ & $r=-0.41, P<0.0001$ \\
\hline
\end{tabular}

and WLFD_W) proved to be poorly determinant and for few individuals.

We highlighted a high inter-individual variability in drivers influencing the use of the littoral zone (Fig. 5). The first axis of the PCA distinguished individuals for which, presence in the littoral zone was mainly dependent on PP and individuals for which presence in the littoral zone was mainly dependent on MT (Fig. 6). In addition, the second axis expressed a hydrological gradient with an opposition between the few individuaIs for which presence in the littoral zone was closely linked to amplitude of WLF (WLDif_D and WLDif_W), and the individuals for which presence in the littoral zone resulted mainly of the WL. Finally, grouping individuals by species revealed an absence of common pattern.

\subsection{Activity}

For the three species, the home range $95 \%$ and the mean minimum distance covered per day showed a high seasonal variability (Tab. VI). For pikeperch and perch, these two variables decreased between summer and winter. In contrast, even if the number of individuals observed was low, it would appear that home range of pike was greater in winter than in summer and that its daily activity was comparable during the two periods.

In summer, perch occupied the largest home range and pike was the least mobile. In winter, perch had the smallest home range. The highest HR 95\% (42.7) was observed for a pike individual. Distances covered by perch 


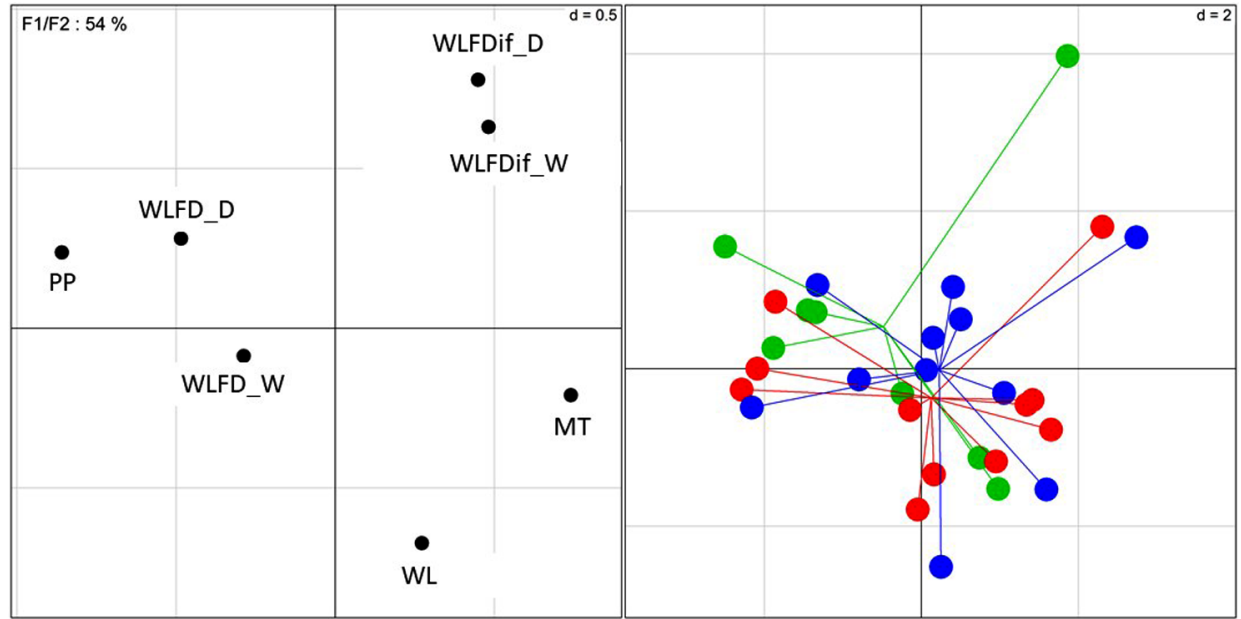

Fig. 6. Positions of variables (on left) and grouping of 30 individuals per species (on right, pikeperch in blue, perch in red and pike in green) on PCA axes F1/F2 to see the influence of the environmental variables on the presence / absence of fish individuals in the littoral zone.

Fig. 6. Positions des variables (à gauche) et regroupement des 30 individus par espèces (à droite, individus de sandre en bleu, perche en rouge et brochet en vert) sur les axes F1/F2 de l'ACP permettant d'évaluer l'influence des variables environnementales sur la présence/absence des individus en zone littorale.

Table VI. Mean values, range of variability between individuals (in italic) and sample size (in bracket) for Home Range 95 \% (HR 95\% in ha) and Minimum Distance Covered per Day (m) for each species, in summer and winter.

Tableau 6. Valeurs moyennes des Home Range $95 \%$ (HR 95\% en ha) et des Distance Minimale Parcourue par Jour $(\mathrm{m})$ pour chaque espèce en été et en hiver, gamme de variabilité inter-individuelle en italique et taille de l'échantillon entre parenthèse.

\begin{tabular}{|c|c|c|c|c|c|c|}
\hline & \multicolumn{2}{|c|}{ Pikeperch } & \multicolumn{2}{|c|}{ Perch } & \multicolumn{2}{|c|}{ Pike } \\
\hline & Summer & Winter & Summer & Winter & Summer & Winter \\
\hline Mean distance covered & $\begin{array}{l}18.1 \\
2.3-56.1 \\
(n=13) \\
4610 \\
(n=476) \\
1552-9135 \\
(n=17)\end{array}$ & $\begin{array}{l}16.3 \\
5.2-29.7 \\
(n=10) \\
2395 \\
(n=361) \\
1004-3716 \\
(n=11)\end{array}$ & $\begin{array}{l}29.8 \\
7.1-60.5 \\
(n=11) \\
5570 \\
(n=145) \\
4020-8160 \\
(n=12)\end{array}$ & $\begin{array}{l}11.0 \\
3.2-28.5 \\
(n=12) \\
2284 \\
(n=418) \\
857-2978 \\
(n=12)\end{array}$ & $\begin{array}{l}10.4 \\
6.3-12.8 \\
(n=4) \\
2625 \\
(n=45) \\
1724-4124 \\
(n=5)\end{array}$ & $\begin{array}{l}23.2 \\
7.3-42.7 \\
(n=6) \\
2883 \\
(n=87) \\
1695-3946 \\
(n=5)\end{array}$ \\
\hline
\end{tabular}

and pikeperch were higher in summer than in winter. They were also higher than those recorded for pike. The highest distance covered was more than $9 \mathrm{~km}$ for one of the pikeperch individuals. There was however a high inter-individ- ual variability of the level of activity within each species, both in summer and in winter (Tab. VI and Fig. 7).

For 10 individuals (6 pikeperch and 4 perch), MT was the main explicative driver of the temporal variability of 

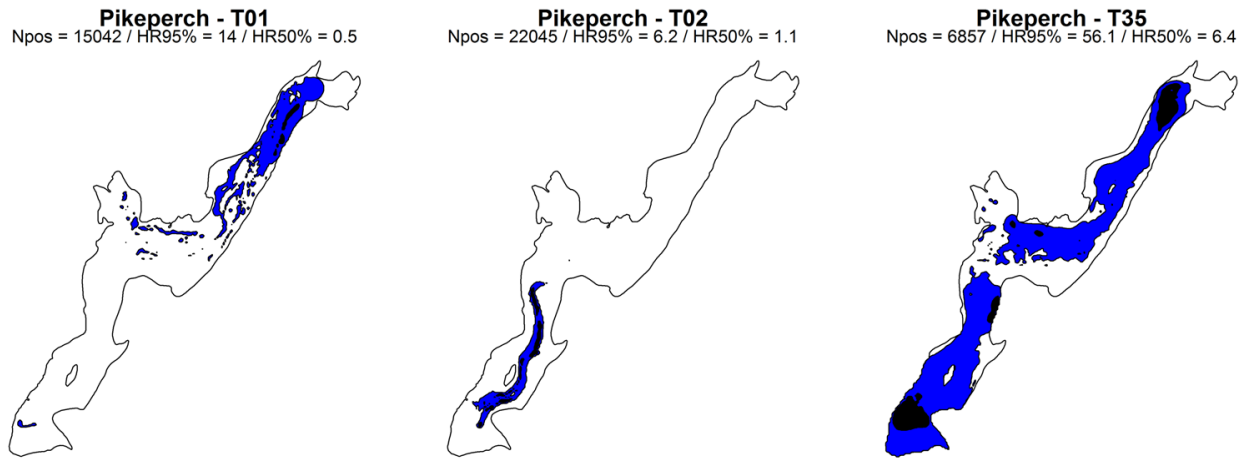

Perch - T28

Perch - T48
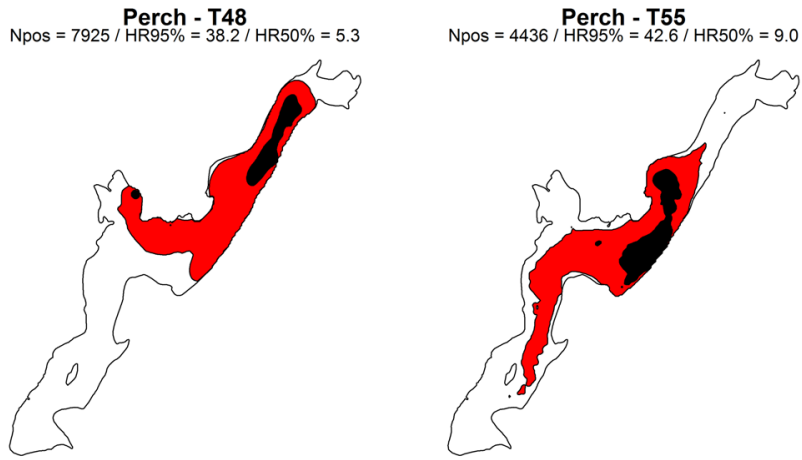

Pike - T04
Npos $=1351 / \mathrm{HR} 95 \%=15.1 / \mathrm{HR} 50 \%=3.1$
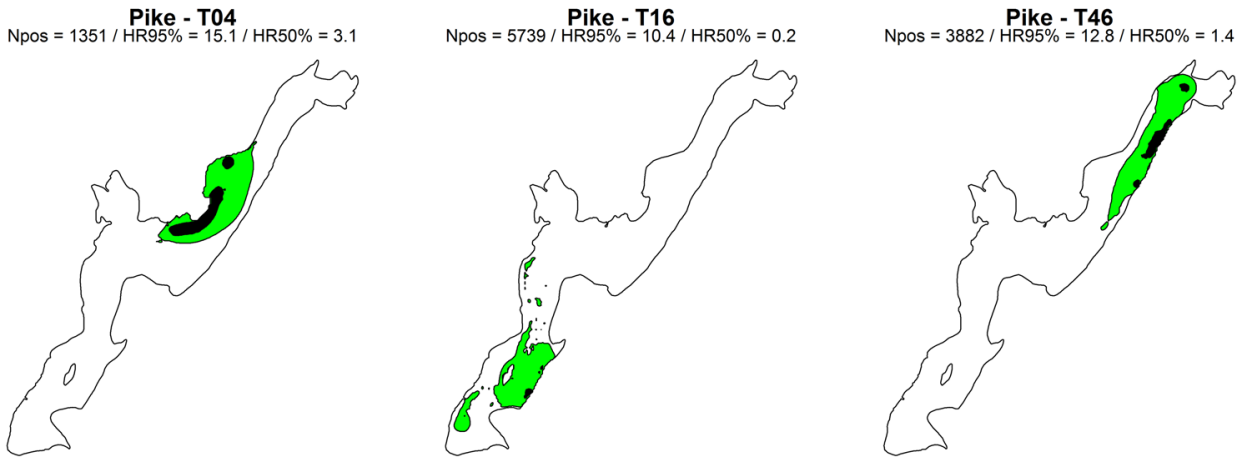

Fig. 7. Home range $95 \%$ in colour and $50 \%$ in black of 3 pike-perch individuals (T01, T02, T35, in blue), 3 perch individuals (T28, T48, T55 in red) and 3 pike individuals (T04, T16, T46, in green) during summer.

Fig. 7. Domaine vital $95 \%$ en couleur et $50 \%$ en noir de 3 individus de sandre (T01, T02, T35, en bleu), de 3 individus de perche (T28, T48, T55, en rouge), et de 3 individus de brochet (T04, T16, T46, en vert) en période estivale.

minimum distance covered per day. The percentage of variation associated with this parameter varied between 25 and $77 \%$ according to the individuals. The coefficient of the regression model associated with this variable, always 
positive, showed that daily activity of these individuals moved in the same direction as MT.

Hydrological parameters (WL, WLDif_D and WLDif_W) contributed to explain part of variability of the daily activity but for a lower number of individuals of pikeperch and perch than MT. Activity of 6 individuals (2 perch and 4 pikeperch) was influenced by water level (contribution from 13 to 39 for WL). The coefficients associated with this variable, always negative, showed that activity and water level were negatively correlated. The responses to the amplitude of past variations (WLDif_D and WLDif_W) were more variable. For some individuals, the activity increase (positive coefficient) with the amplitude of the past variations and conversely for others (negative coefficient).

The 4 numerical environmental variables selected did not provide an explanation for the variability of the minimum distance covered per day of 8 individuals. Residual parts of the regression models were then higher than $80 \%$ and adjusted coefficient $\mathrm{R}^{2}$ lower than 0.2.

\section{Discussion}

\subsection{Effect of water level fluctuations on habitats}

A drop in water level in the Bariousses reservoir led to a diminution of surface covered by the littoral zone. A maximum surface was observed at $510.9 \mathrm{~m}$ NGF. In addition, a trend towards a dominance of the fine substrates (sand and silt) and an absence of vegetation was shown confirming our initial hypothesis. The precise quantification of changes in the availability and quality of littoral habitats induced by the lowering of water level that we described here confirmed a general trend towards a reduction in habitat complexity with the lowering of water level. Similar studies are rare but our results confirmed the observations made in Lake Kinneret (Gasith \& Gafny, 1990, 1998) and Lake Tahoe (Beauchamp et al., 1994). Considering the interest of the littoral zone for fish fauna (Schiemer et al., 1995; Schmieder, 2004; Lewin et al., 2014), alterations of littoral habitats due to water level decrease are likely to affect fish community. Indeed, we could expect for example an increased exposure to predation due to loss of refuge area in the littoral zone (Kahl \& Radke, 2006). Similarly, these changes could induce a decline in available food resources (Zohary \& Ostrovsky, 2011). Specific study of patterns of change in littoral fish community composition sampled by elecrofishing (individuals less than $250 \mathrm{~mm}$ ) following changes in habitat conditions induced by WLF confirms this hypothesis (Logez et al., 2016). In the Bariousses reservoir, the relationship between habitat complexity and fish assemblage changed along the water-level gradient. A homogenization of fish assemblages was observed when the water-level condition reached a threshold. These results suggest an effect of water-level management in structuring fish assemblages of the littoral zone of a reservoir due to a decrease of habitat complexity. 


\subsection{Lateral migration}

The spatial distribution patterns of individuals of the 3 species were subject to high seasonal variability. Drop in water temperature resulted in movements towards deeper waters, associated with movements away from the shore. Previous studies observed similar seasonal patterns of change for pikeperch (Deelder \& Willemsen, 1964; Nyberg et al., 1996; Vehanen \& Lahti, 2003; Lehtonen et al., 2006) and pike (Rogers, 1998; Jepsen et al., 2001). In addition, our study revealed the key role of water temperature in the littoral zone occupation. During cold periods, the littoral zone was more thermally unstable than the pelagic zone and that may partially explain why individuals left the littoral zone during these periods. Furthermore, decline in juvenile abundance between spring and winter, regularly observed in the littoral zone (Brosse \& Lek, 2000; Brosse et al., 2007), may be one of the causes of the drop in frequentation of this zone by piscivorous adults of pikeperch, perch and pike.

In addition of temperature, photoperiod was also a driver of the frequentation of the littoral zone, in the same way as water temperature. Individuals were more frequent in the littoral zone at night, dawn and dusk to take advantage either of the greater structural complexity in order to rest or to be protected from predators, or of the greater abundance of prey to feed on (Sanders, 1992; Copp \& Jurajda, 1993, 1999; Horky et al., 2008).

\subsection{Role of water temperature and photoperiod on fish activity}

Ours results highlight that water temperature and photoperiod were factors contributing to understand fish activities. Perch and pikeperch were less mobile when temperature dropped. This decline in perch activity in relation with water temperature was already observed in various hydrosystems (Craig, 1977; Eriksson, 1978; Karas \& Thoresson, 1992; Huusko et al., 1996; Neuman et al., 1996; Jacobsen et al., 2002) but for pikeperch, our observations differed from those of Koed et al. (2000) and Jepsen et al. (1999) who observed a low significant correlation between the total distance moved and water temperature. In contrast, the drop in water temperature observed between the beginning of summer and the middle of winter did not appear to clearly affect pike activity showing some species differences. There is no consensus in the literature regarding the role played by water temperature on pike behaviour: some studies showed a decline in activity between summer and winter (Casselman, 1978; Cook \& Bergersen, 1988; Rogers, 1998; Kobler et al., 2008a), others an increase (Jepsen et al., 2001; Koed et al., 2006), or even no difference (Diana et al., 1977). This absence of consensus might be explained by site differences, in particular in terms of prey availability, shore structure, availability of preferred habitats or perhaps in monitoring methods and/or triangulation techniques used (Rogers, 1998; Jepsen et al., 2001). 


\subsection{Influence of hydrological parameters on fish position and activity}

Hydrological parameters considered in this study contributed to explain only a part of the behavioural variability of pikeperch, perch and pike individuals (length greater than $250 \mathrm{~mm}$ ). However, some individuals showed greater mobility ( $n=6$, perch and pikeperch) and lesser use of the littoral zone at low water levels, when littoral habitat was more homogeneous (dominance of fine substrates without vegetation). These results are similar to those of Bruylants et al. (1986), who showed higher mobility for perch in homogeneous areas (similar depth, substrate and current) than in heterogeneous areas (succession of pool/riffle) of rivers. Dispersal of favourable patches when habitat is homogeneous (low water level) might explain these observations (Baras, 1992), since individuals must then cover greater distances to reach favourable habitats for accomplishing their vital functions (reproduction, rest/ protection and food seeking). The lowest frequentation of the littoral zone observed at low water levels might be explained by the decline in attractiveness of this zone. By comparison, an increased frequentation of the shore when flow rate raised was regularly observed in rivers (Brenden et al., 2006), as individuals sought to return to refuge zones for protection.

\subsection{Methodological considerations}

The implementation of experiments dedicated to individual behaviour using acoustic telemetry needs preliminary methodological developments. In our experimental conditions, performances of VPS described by the positioning error and the probability of location were proved satisfactory (Roy et al., 2014).

The present study, carried out on a large number of individuals of three species conducted in a same lake during a long period, highlights a very high variability in behavioural responses of individuals to environmental fluctuations. Therefore, we must proceed with extreme caution when behavioural characteristics are attributed to a particular species, in particular when a "mean" value of the spatial distribution and activity metrics is presented. The fish size effect was supposed to explain a part of individual variability: the largest individuals of pikeperch and perch tend to frequent areas that are deeper and further from the shore and the largest individuals of the 3 species tend to cover greater daily distances than smaller individuals, as was observed for pike by Kobler et al. (2008b) and for pikeperch by Jepsen et al. (1999). Nevertheless, further studies are required to identify precisely drivers of inter-individual variability. For example, a monitoring of individuals with the same age and sex characteristics could provide elements to explore their influence on variability among individuals.

These behavioural analyses nonetheless provided initial results that may help us to better understand factors controlling habitats, in particular, in the littoral, under water level management. Extension of these results by further studies in other lake systems impacted by different hydrological regimes might be developed. It could allow finding 
efficient mitigation measures to improve the ecological potential of reservoirs.

\section{ACKNOWLEDGEMENTS}

This study was funded by EDF, Irstea, the Agence de l'Eau Adour-Garonne and ANRT through a CIFRE PhD bursary. We thank Marie-Laure Acolas, Frédérique Bau, Mario Lepage, Charles Roqueplo (Irstea, EPBX), Hervé Capra, Nicolas Lamouroux (Irstea, DYNAM), Céline Le Pichon (Irstea, HBAN), MarieLaure Begout (Ifremer), Jean Guillard, Jean-Christophe Hustache and Thomas Poulain (INRA Thonon-les-Bains) for the loan of equipment and their technical scientific support. We also thank Stéphanie Smedbol, Franck Smith and Dana Allen of Vemco for their support in the use of the telemetry system. Finally, we thank the staff of the Vézère hydroelectric plant, Tim Kestens of the EDF Centre production unit, Hugues Peyret (EDF CIH), and voluntary helpers from Treignac AAPPMA, and anglers who helped us to catch fish for tagging.

Thank you all.

\section{REFERENCES}

Alleaume S., Heyd C., Lanoiselée C. \& Argillier C., 2014. Charli: Protocole de caractérisation des habitats des rives et $d u$ littoral (version 2014). Aix en Provence: Irstea, $30 \mathrm{p}$.

Aroviita J. \& Hamalainen H., 2008. The impact of water-level regulation on littoral macroinvertebrate assemblages in boreal lakes. Hydrobiologia 613: 45-56.

Baras E., 1992. Time and space utilization strategies in the common barbel Barbus barbus (L.). Cah. Ethol. Appl. 12(2-3): 125-442.
Baumgartner D., Mortl M. \& Rothhaupt K. O., 2008. Effects of water-depth and water-level fluctuations on the macroinvertebrate community structure in the littoral zone of Lake Constance. Hydrobiologia 613: 97-107.

Beauchamp D.-A., Byron E.-R. \& Wurtsbaugh W.-A., 1994. Summer habitat use by littoral-zone fishes in lake Tahoe and the effects of shoreline structures. N. Am. J. Fish Manage. 14: 385-394.

Brauns M., Garcia X.F. \& Pusch M.T., 2008. Potential effects of water-level fluctuations on littoral invertebrates in lowland lakes. Hydrobiologia 613: 5-12.

Brenden T.O., Murphy B.R. \& Hallerman E. M., 2006. Effect of discharge on daytime habitat use and selection by muskellunge in the New River, Virginia. T. Am. Fish Soc. 135(6): 1546-1558.

Brosse S. \& Lek S., 2000. Ontogenetic microhabitat shifts of $0+$ rudd (Scardinius erythrophthalamus L.) in the littoral zone of a mesotrophic lake. Verh. Internat. Verein Limnol. 27: 1-3.

Brosse S., Grossman G.D. \& Lek S., 2007. Fish assemblage patterns in the littoral zone of a European reservoir. Freshw. Biol. 52(3): 448-458.

Bruylants B., Vandelannoote A. \& Verheyen R., 1986. The movement pattern and density distribution of perch, Perca fluviatilis L., in a channelized lowland river. Aquacult. Fish. Manage. 17: 49-57.

C.E.N. 2005. Qualité de l'eau. - Échantillonnage des poissons à l'aide de filets maillants (NF EN 14757), 29.

Calenge C., 2006. The package "adehabitat" for the R software: a tool for the analysis of space and habitat use by animals. Ecol. Model. 197(3-4): 516519.

Calenge C., 2013. Package "adehabitatLT". 1-94. 
Casselman J.M., 1978. Effects of environmental factors on growth, survival, activity, and exploitation of northern pike. Am. Fish S. 11: 114-128.

Chevan A. \& Sutherland M., 1991. Hierarchical partitioning. Am. Stat. 45(2): 90-96.

Clark M.E., Rose K.A., Chandler J.A., Richter T.J., Orth D.J. \& Van Winkle W., 2008. Water-level fluctuation effects on centrarchid reproductive success in reservoirs: a modeling analysis. $N$. Am. J. Fish Manage. 28(4): 1138-1156.

Cook M.F. \& Bergersen E.P., 1988. Movements, habitat selection, and activity periods of Northern Pike in 11 mile reservoir, Colorado. T. Am. Fish Soc. 117(5): 495-502.

Copp G.H. \& Jurajda P., 1993. Do small riverine fish move inshore at night? J. Fish Biol. 43: 229-241.

Copp G.H. \& Jurajda P., 1999. Size-structured diel use of river banks by fish. Aquat. Sci. 61(1): 75-91.

Craig J.F., 1977. Seasonal changes in day and night activity of adult perch, Perca fluviatilis L. J. Fish Biol. 11(2): 161-166.

Day T. \& Garratt R., 2006. Lakes and Rivers. Chelsea house publishers: $258 p$.

Deelder C. \& Willemsen J., 1964. Synopsis of biological data on pike-perch Lucioperca lucioperca (Linnaeus 1758). FAO Fish. 28: 1-52.

Diana J.S., Mackay W.C. \& Ehrman M., 1977. Movements and habitat preference of Northern Pike (Esox Lucius) in Lac Ste Anne, Alberta. T. Am. Fish Soc. 106(6): 560-565.

Eriksson L.O., 1978. A laboratory study of diel and annual activity rythms and vertical distribution in the perch, Perca fluviatilis, at the Artic circle. Environ. Biol. Fish 3: 301-307.
Fischer P. \& Ohl U., 2005. Effects of waterlevel fluctuations on the littoral benthic fish community in lakes: a mesocosm experiment. Behav. Ecol. 16(4): 741746.

Gasith A. \& Gafny S., 1990. Effects of water level fluctuation on the structure and function of the littoral zone. In: Large Lakes: Ecological Structure and Function (M.M. Tilzer and C. Serruya, Eds.), $15 \mathrm{p}$.

Gafny S. \& Gasith A., 1993. Effect of low water-level on the water-quality of the littoral-zone in Lake Kinneret. Water Sci. Technol. 27(7-8): 363-371.

Gasith A. \& Gafny S., 1998. The importance of physical structure in lakes: the case study of Lake Kinneret and general implications In: The structuring role of submerged macrophytes in lakes (E. Jeppesen, M.A. Sondergaard, M.O. Sondergaard and K. Christoffersen, Eds.), $7 \mathrm{p}$.

Gafny S., Gasith A. \& Goren M., 1992. Effect of water level fluctuation on shore spawning of Mirogrex terraesanctae (Steinitz), (Cyprinidae) in lake Kinneret, Israel. J. Fish Biol. 41(6): 863-871.

Gasith A., Gafny S. \& Goren M., 2000. Response of the fish assemblage of rocky habitats to lake level fluctuations: possible effect of varying habitat choice. Arch. Hydrobiol. 55( Special issues Advances in Limnology): 317-331.

Horky P., Slavik O. \& Bartos L., 2008. A telemetry study on the diurnal distribution and activity of adult pikeperch, Sander lucioperca (L.), in a riverine environment. Hydrobiologia 614(1): 151-157.

Horne J.S., Garton E.O., Krone S.M. \& Lewis J.S., 2007. Analyzing animal movements using Brownian bridges. Ecology 88(9): 2354-2363. 
Huusko A., Vuorimies O. \& Sutela T., 1996. Temperature- and light-mediated predation by perch on vendace larvae. $J$. Fish Biol. 49(3): 441-457.

Irz P., Laurent A., Messad S., Pronier O. \& Argillier C., 2002. Influence of site characteristics on fish community patterns in French reservoirs. Ecol. Freshw. Fish 11(2): 123-136.

Jacobsen L., Berg S., Broberg M., Jepsen N. \& Skov C., 2002. Activity and food choice of piscivorous perch (Perca fluviatilis) in a eutrophic shallow lake: a radio-telemetry study. Freshw. Biol. 47(12): 2370-2379.

Jepsen N., Koed A. \& Okland F., 1999. The movements of pikeperch in a shallow reservoir. J. Fish Biol. 54(5): 1083-1093.

Jepsen N., Beck S., Skov C. \& Koed A., 2001. Behavior of pike (Esox lucius L.) $>50 \mathrm{~cm}$ in a turbid reservoir and in a clearwater lake. Ecol. Freshw. Fish 10: 26-34.

Kahl U. \& Radke R.J., 2006. Habitat and food resource use of perch and roach in a deep mesotrophic reservoir: enough space to avoid competition? Ecol. Freshw. Fish 15(1): 48-56.

Kahl U., Hulsmann S., Radke R.J. \& Benndorf J., 2008. The impact of water level fluctuations on the year class strength of roach: Implications for fish stock management. Limnologica 38(34): 258-268.

Karas P. \& Thoresson G., 1992. An application of a bioenergetics model of Eurasian perch (Perca fluviatilis L.). J. Fish Biol. 41: 217-230.

Katajisto J. \& Moilanen A., 2006. Kernelbased home range method for data with irregular sampling intervals. Ecol. Model. 194(4): 405-413.

Kobler A., Klefoth T. \& Arlinghaus R., 2008a. Site fidelity and seasonal changes in activity centre size of female pike Esox lucius in a small lake. J. Fish Biol. 73(3): 584-596.
Kobler A., Klefoth T., Wolter C., Fredrich F. \& Arlinghaus R., 2008b. Contrasting pike (Esox lucius L.) movement and habitat choice between summer and winter in a small lake. Hydrobiologia 601: 17-27.

Koed A., Mejlhede P., Balleby K. \& Aarestrup $\mathrm{K}$., 2000. Annual movement and migration of adult pikeperch in a lowland river. J. Fish Biol. 57: 1266-1279.

Koed A., Balleby K., Mejlhede P. \& Aarestrup K., 2006. Annual movement of adult pike (Esox lucius L.) in a lowland river. Ecol. Freshw. Fish 15(2): 191199.

Legendre P. \& Legendre L., 1998. Numerical ecology. Amsterdam: Elsevier Science, $853 \mathrm{p}$.

Lehtonen H., Lappalainen J., Kervinen J. \& Fontell E., 2006. Spatial distribution of spawning sites of pikeperch Sander lucioperca (L.) in a highly eutrophic clayturbid lake - implications for management. J. Appl. Ichthyol. 22(6): 540-542.

Leira M. \& Cantonati M., 2008. Effects of water-level fluctuations on lakes: an annotated bibliography. Hydrobiologia 613: 171-184.

Lewin W.C., Mehner T., Ritterbusch D. \& Braemick U., 2014. The influence of anthropogenic shoreline changes on the littoral abundance of fish species in German lowland lakes varying in depth as determined by boosted regression trees. Hydrobiologia 724(1): 293-306.

Logez M., Roy R., Tissot L. \& Argillier C., 2016. Effects of water-level fluctuations on the environmental characteristics and fish-environment relationships in the littoral zone of a reservoir. Fund. Appl. Limnol. 189(1): 37-49.

Neuman E., Thoresson G. \& Sandstrom O., 1996. Swimming activity of perch, Perca fluviatilis, in relation to temperature, day-length and consumption. Ann. Zool. Fenn. 33(3-4): 669-678. 
Nyberg P., Degerman E. \& Sers B., 1996. Survival after catch in trap-nets, movements and growth of the pikeperch (Stizostedion lucioperca) in Lake Hjaelmaren, Central Sweden. Ann. Zool. Fenn. 33: 569-575.

Observ'ER, 2013. La production d'électricité d'origine renouvelable dans le monde. 1. La production d'électricité dans le monde: perspectives générales. Observ'ER, EDF et Fondation énergies pour le monde: $5 \mathrm{p}$.

Ostrovsky I. \& Walline P., 2000. Multiannual changes in the pelagic fish Acanthobrama terraesanctae in Lake Kinneret (Israel) in relation to food sources. Verh. Internat. Verein Limnol. 27: 2090-2094.

Ostrovsky I., Rimmer A., Yacobi Y.Z., Nishri A., Sukenik A., Hadas O. \& Zohary T., 2013. Long-term changes in the lake Kinneret ecosystem: the effects of climate change and anthropogenic factors. In: Climatic change and global warming of inland waters: impacts and mitigation for ecosystems and societies (C.R. Goldman, M. Kumagai and R.D. Robarts, Eds.), 24 p.

Parsons D.M., Babcock R.C., Hankin R.K. S., Willis T.J., Aitken J.P., O'Dor R.K. \& Jackson G.D., 2003. Snapper Pagrus auratus (Sparidae) home range dynamics: acoustic tagging studies in a marine reserve. Mar. Ecol. Prog. Ser. 262: 253-265.

Poff N.L., Allan J.D., Bain M.B., Karr J.R., Prestegaard K.L., Richter B.D., Sparks R.E. \& Stromberg J.C., 1997. The natural flow regime: a paradigm for river conservation. Bioscience 47(11): 769-784.

Poirel A., Merle G., Salençon M.J. \& Travade F., 2001. Gestion hydraulique et ressources piscicoles dans les retenues hydroélectriques. In: Gestion Piscicole des grands plans d'eau (INRA Ed.), $458 p$.
R.C.T., 2012. R: A language and environment for statistical computing. Vienna, Austria: R Foundation for Statistical Computing. http://www.R-project.org/. ISBN 3-900051-07-0.

Ramade F., 2009. Éléments d'écologie Écologie Fondamentale $-4^{e}$ Edition.

Rebière D., Argillier C. \& Roy R., 2012. Caractérisation environnementale de la retenue des Bariousses (Treignac, Corrèze). Irstea: $47 \mathrm{p}$.

Rogers K.B., 1998. Habitat use by largemouth bass and northern pike on the rocky mountain Arsenal, Colorado. In: Colorado State University Fort Collins $414 \mathrm{p}$.

Rose K.A., 2000. Why are quantitative relationships between environmental quality and fish populations so elusive? Ecol. Appl. 10(2): 367-385.

Roy R., 2014. Distribution spatiale et activité des poissons en milieu lacustre : impacts des facteurs environnementaux à partir d'une approche multiéchelle. Application à la retenue des Bariousses. In: École Doctorale Science de l'Environnement, $224 \mathrm{p}$.

Roy R., Beguin J., Argillier C., Tissot L., Smith F., Smedbol S. \& De-Oliveira E., 2014. Testing the VEMCO Positioning System: spatial distribution of the probability of location and the positioning error in a reservoir. Anim. Biotelem. 2 (1): $1-6$.

Sanders R.E., 1992. Day versus night electrofishing catches from near-shore waters of the Ohio Muskingum rivers. Ohio J. Sci. 92(3): 51-59.

Schiemer F., Zalewski M. \& Thorpe J.E., 1995. Land and inland water ecotones - intermediate habitats critical for conservation and management. Hydrobiologia 303(1-3): 259-264.

Schindler D.E. \& Scheuerell M.D., 2002. Habitat coupling in lake ecosystems. Oikos 98(2): 177-189. 
Schlosser I.J., 1995. Critical landscape attributes that influence fish population-dynamics in headwater streams. Hydrobiologia 303(1-3): 71-81.

Schmieder K., 2004. European lake shores in danger - concepts for a sustainable development. Limnologica 34(1-2): 3-14.

Smith F., 2013. Understanding HPE in the VEMCO Positioning System (VPS), V1. 0 , September 27, 2013. Retrieved on September 27, 2013 from [http://vemco. com/wp-content/uploads/2013/09/un derstanding-hpe-vps.pdf].

Smith B.D., Maitland P.S. \& Pennock S.M., 1987. A comparative-study of water level regimes and littoral benthic communities in Scottish lochs. Biol. Conserv. 39(4): 291-316.

Strayer D.L. \& Findlay S.E.G., 2010. Ecology of freshwater shore zones. Aquat. Sci. 72(2): 127-163.

Sutela T. \& Vehanen T., 2008. Effects of water-level regulation on the nearshore fish community in boreal lakes. Hydrobiologia 613: 13-20.

Valdovinos C., Moya C., Olmos V., Parra O., Karrasch B. \& Buettner O., 2007. The importance of water-level fluctuation for the conservation of shallow water benthic macroinvertebrates: an example in the Andean zone of Chile. Biodivers. Conserv. 16: 3095-3109.

Vehanen T. \& Lahti M., 2003. Movements and habitat use by pikeperch (Stizostedion lucioperca (L.)) in a hydropeaking reservoir. Ecol. Freshw. Fish 12(3): 203-215.

VEMCO Division A.S.I. 2008. VR2W Positioning System (VPS) User Manual (2008).
VEMCO Division A.S.I. 2013. VR2W Positioning System (VPS) Results Description (2013).

Webb P.W., 2008. The impact of changes in water level and human development on forage fish assemblages in great lakes coastal marshes. J. Great Lakes Res. 34(4): 615-630.

Wetzel R.G., 1990. Reservoir ecosystems: conclusions and speculations. In: Reservoir limnology: ecological perspective (K.W. Thornton, B.L. Kimmel and F. E. Payne Eds.), $11 \mathrm{p}$.

White M.S., Xenopoulos M.A., Hogsden K., Metcalfe R.A. \& Dillon P.J., 2008. Natural lake level fluctuation and associated concordance with water quality and aquatic communities within small lakes of the Laurentian Great Lakes region. Hydrobiologia 613: 21-31.

Wilcox D.A. \& Meeker J.E., 1992. Implications for faunal habitat related to altered macrophyte structure in regulated lakes in Northern Minnesota. Wetlands 12(3): 192-203.

World-Commission-on-Dams, 2000. Dams and Development - A new framework for decision-making. $356 \mathrm{pp}$.

Zamora L. \& Moreno-Amich R., 2002. Quantifying the activity and movement of perch in a temperate lake by integrating acoustic telemetry and a geographic information system. Hydrobiologia 483(1-3): 209-218.

Zohary T. \& Ostrovsky I., 2011. Ecological impacts of excessive water level fluctuations in stratified freshwater lakes. Inland Waters 1: 47-59. 